\title{
EXPERIÊNCIAS DOCENTES E CULTURAS POLÍTICAS: $O$ PROFESSOR DE PRIMEIRAS LETRAS JOÃO BAPTISTA BRANDÃO DE PROENÇA (5a COMARCA DA PROVÍNCIA DE SÃO PAULO/PROVÍNCIA DO PARANÁ. 1830-1860)
}

DOI: http://dx.doi.org/10.1590/2236-3459/69297

Fabiana Garcia Munhoz

Universidade de São Paulo, Brasil.

Diana Gonçalves Vidal

Universidade de São Paulo, Brasil.

$\cos 80$

\begin{abstract}
Resumo
Este artigo problematiza historicamente as experiências de um professor de primeiras letras de Curitiba entre as décadas de 1830 e 1860 com o objetivo de acompanhar os modos como o mestre João Baptista Brandão de Proença foi se produzindo como professor, funcionário público e intelectual. Num período marcado pela oralidade e escassa presença de instituições de formação, o artifício metodológico de acompanhar sua trajetória permitiu perceber como a experiência docente foi sendo construída na tessitura da circulação de sujeitos em diferentes espaços sociais e por meio do acúmulo de um repertório pedagógico, legal e políticoadministrativo. Personagem "excepcional normal", como consideraria Carlo Ginzburg (2007, p. 277), João Baptista Brandão de Proença indicia os percalços sofridos e as astúcias empregadas pelos primeiros mestres Oitocentistas na produção da docência como ofício.
\end{abstract}

Palavras-chave: experiência docente, instrução pública, culturas políticas.

\section{TEACHING EXPERIENCES AND POLITICAL CULTURES: THE TEACHER OF FIRST LETTERS JOÃO BAPTISTA BRANDÃO DE PROENÇA (5TH COMARCA DA PROVÍNCIA DE SÃO PAULO/PROVÍNCIA DO PARANÁ - 1830-1860)}

\begin{abstract}
This article discusses the historical experiences of a teacher of first letters in Curitiba between 1830s and 1860 s in order to realize the ways in which João Baptista Brandão de Proença became a primary teacher, public servant and intellectual. In a period marked by orality and scarcity of teachers' training institutions, track his trajectory, as a methodological approach, allows understanding teaching experience as a construction intertwining circulation of individuals in different social spaces and accumulation of a pedagogical, legal, political and administrative repertory. "Normal exceptional" personage, as Carlo Ginzburg consider (2007, p. 277), João Baptista Brandão de Proença offers clues to the mishaps suffered and astuteness employed by the early nineteenth-century teachers in the production of teaching as a craft.

Keywords: teaching experience, public education, political cultures.
\end{abstract}


EXPERIENCIAS DOCENTES Y CULTURAS POLÍTICAS: EL MAESTRO DE PRIMERAS LETRAS JOÃO BAPTISTA BRANDÃO DE PROENÇA (5a COMARCA DA PROVÍNCIA DE SÃO PAULO/PROVÍNCIA DO PARANÁ - 1830-1860)

\section{Resumen}

En este artículo se analiza la trayectoria histórica de un maestro de primeras letras de Curitiba entre los años 1830 y 1860 con el propósito de seguir el modo como João Baptista Brandão de Proença se fue produciendo en tanto que maestro, funcionario público e intelectual. En un período marcado por la oralidad y la escasa presencia de las instituciones de formación, el procedimiento metodológico de seguir su trayectoria nos permite percebir cómo la experiencia docente se estava construyendo en la tesitura de la circulación de los sujetos en distintos espacios sociales y por medio de la acumulación de un repertorio pedagógico, jurídico, político y administrativo. Personage "normal excepcional", como lo considera Carlo Ginzburg (2007, p. 277), João Baptista Brandão de Proença ofrece huellas de los percances sufridos y los trucos empleados por los maestros de principios del siglo XIX en la producción de la enseñanza como un oficio.

Palabras claves: experiencia docente, la educación pública, culturas políticas.

\section{EXPÉRIENCES D'ENSEIGNEMENT ET DES CULTURES POLITIQUES: L'ENSEIGNANT DES PREMIĖRES LETTRES JOÃO BAPTISTA BRANDÃO DE PROENÇA (5ĖME COMARCA DA PROVÍNCIA DE SÃO PAULO/PROVÍNCIA DO PARANẢ - 1830-1860)}

\section{Resumé}

Cet article traite de la trajectoire historique d'un enseignant de premières lettres de Curitiba entre les années 1830 et 1860. L'objectif est comprendre comment João Baptista Brandão de Proença s'est fabriqué en tant que instituteur, fonctionnaire et intellectuelle. Dans une période marquée par l'oralité et la rareté des institutions de formation, le dispositif méthodologique de suivre sa trajectoire a permis de voir comment l'expérience de l'enseignement a été construite dans la trame du circulation des sujets dans les différents domaines et les groupes sociaux, en profitant de l'accumulation d'un répertoire éducatif, juridique, politique et administrative. Personnage "exceptionnel normal", comme Carlo Ginzburg considère (2007, p. 277), João Baptista Brandão de Proença offre les indices du mésaventures et astuces employés par les instituteurs au début du XIXe siècle dans la fabrication de l'enseignement comme un métier.

Mots-clés: expérience enseignante, l'éducation publique, cultures politiques. 
Raiou, oh pátria querida

O dia da separação

É província Curityba

Por vontade da nação

$[\ldots]$

Paraná é nova estrella

Do diadema imperial.

Nova província do Império, Nova filha de Cabral.

Povo leal curitybano Publicai vossa alegria Festejando ao Presidente Que o monarca nos envia.

Ao monarca brasileiro, Aos poderes da Nação, Concordes agradecemos Nossa emancipação.

(PROENÇA, 1853 apud STRAUBE, 2002, p. 81-82).

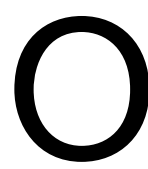

s excertos acima são estrofes do primeiro hino da Província do Paraná, antiga 5a . Comarca da Província de São Paulo¹, emancipada em 19 de dezembro de 1853, data da posse do presidente Zacarias Góes e Vasconcellos ${ }^{2}$. Tratava-se de uma das regiões menos populosas e povoadas do Brasil Imperial.

O evento de importância política e social teve particular significado para o professor público de primeiras letras de Curitiba João Baptista Brandão de Proença, protagonista deste estudo. Por iniciativa própria ou a convite, compôs o Hino à Província do Paraná cantado na instalação da província ${ }^{3}$, que foi executado publicamente por um coro de vozes infantis, de seus alunos, na solenidade de posse de Góes e Vasconcellos. Segundo Straube

\footnotetext{
${ }^{1}$ A Província de São Paulo constituía-se em um território bem maior do que o do atual estado paulista, fazia fronteira com a Província do Rio Grande do Sul e era composta, em 1852, por 7 comarcas. A 1aㅡ comarca abrangia a região do Vale do Paraíba, a $2^{\underline{a}}$ a da capital e a região de Atibaia e Bragança Paulista, a $3^{\mathrm{a}}$ a região de Jundiaí a Araraquara, a $4^{\mathrm{a}}$ a região de Sorocaba, a $5^{\mathrm{a}}$ a do atual Paraná abrangendo as cidades de Curitiba e Paranaguá e as vilas de Morretes, Castro, Ponta Grossa, Antonina dentre outras, a 6⿳亠丷厂 0 litoral de São Paulo e a $7^{\mathfrak{a}}$ abrange a região de Franca. Cf. Relação das escolas de primeiras letras da Província de São Paulo, elaborada pelo secretário do governo Francisco José de Lima, em 15 de abril de 1852. Anexa ao Discurso com que o illustrissimo e excellentissimo senhor dr. José Thomaz Nabuco d'Araujo, presidente da provincia de São Paulo, abrio a Assembléa Legislativa Provincial no dia 1.o de maio de 1852. São Paulo, na Typ. do Governo arrendada por Antonio Louzada Antunes, 1852.

${ }^{2} \mathrm{O}$ baiano Conselheiro Zacarias, como era conhecido, já havia presidido as províncias do Piauí e de Sergipe quando assumiu a província recém-criada aos 39 anos. "Iniciou-se na vida pública no Partido Conservador, do qual se retiraria em 1861, para ingressar na Liga Constitucional, aliança firmada entre conservadores moderados e liberais progressistas que acarretou na formação do Partido Progressista" (Guimarães, 2008, p. 724). Posteriormente ganhou projeção por suas reflexões acerca do poder moderador. Na província do Paraná, segundo Wilson Martins (1999, p. 27), foi incumbido de colocar em execução um programa que criasse as condições para o governo e administração da nova província. Tal programa foi traçado a partir das instruções recebidas do ministro do Império, Luiz Pedreira do Couto Ferraz (1818-1886). Ainda de acordo com Martins (1999), governou em consonância com o poder central e com o apoio do poder local.

3 Não se trata do atual hino estadual do Paraná, escrito em 1903 e oficializado em 1923, que tem letra de Domingos Virgílio do Nascimento (1862-1915) e música de Bento D’Albuquerque Mossurunga (1879-1970). Segundo Ernani Costa Straube (2002), o Paraná teve três hinos antes do atual. O primeiro de autoria do professor de primeiras letras João Baptista Brandão de Proença de 1853 - único do período imperial; o segundo de 1893 com música de Eugênio Nogueira e letra de Francisco Azevedo Macedo; o terceiro de 1902 com letra do poeta Gabriel Pereira e música do maestro Major Bento de Menezes.
} 
Na noite de 19 de dezembro de 1853, por ocasião das solenidades de posse do primeiro Presidente da Província do Paraná, Zacarias de Góes e Vasconcellos, foi executado o "Hino à Província do Paraná", também denominado "Hino da Emancipação", de autoria do Professor João Baptista Brandão de Proença. O Hino foi cantado pela menina Maria da Glória, com 16 anos de idade (...). A cantora foi acompanhada por um coro de vozes infantis, alunas do autor do Hino. (STRAUBE, 2002, p. 81)

João Baptista Brandão de Proença parece ter tido perspicácia para aproveitar o momento e granjear maior reconhecimento social. Afinal, com a emancipação, deixava de ser mais um professor público de primeiras letras de uma longínqua cidade da $5^{\underline{a}}$ Comarca para se tornar o único professor público de primeiras letras da capital da mais nova província do Império brasileiro ${ }^{4}$. Era a oportunidade ideal para dar maior visibilidade social e política ao trabalho que vinha realizando havia mais de 20 anos no magistério. $O$ espetáculo público do coro de vozes de alunos visava garantir-Ihe o reconhecimento de sua experiência docente. A letra e música do hino afirmavam sua erudição e seu compromisso com o governo provincial e imperial: comemoravam a separação do "povo curitibano" (existia uma disputa entre Paranaguá e Curitiba para sediar a capital da nova província); celebravam a monarquia; festejavam o primeiro presidente da Província do Paraná e agradeciam ao monarca como um bom e leal súdito. De um só "golpe" (CERTEAU, 1994), sintonizava-se com as elites da região e reiterava a posição de intelectual local.

Acompanhar os modos como João Baptista Brandão de Proença foi se produzindo como professor, funcionário público e intelectual é o objetivo deste artigo. $\mathrm{O}$ artifício nos permite perceber como a experiência docente foi sendo construída na tessitura da circulação de sujeitos em diferentes espaços sociais, acumulando um repertório legal e político-administrativo, e no convívio entre pares e comunidade em um período marcado pela escassa presença de instituições de formação (como as Escolas Normais). O conceito de "culturas políticas" serve-nos como fio condutor da análise, instigando-nos a interpretar "comportamentos políticos individuais e coletivos privilegiando suas percepções, suas lógicas cognitivas, suas vivências, suas sensibilidades" (GOMES, 2005, p. 30-31).

\section{Culturas políticas e pertencimento social}

De acordo com as obras de Francisco Negrão e Ermelino Agostinho de Leão 5 , Brandão de Proença teria iniciado a sua "carreira pública" em 1832, ao se tornar sacristão da Igreja Matriz de Curitiba com 19 anos de idade. Pouco se sabe sobre sua origem familiar. Por meio do ingresso no magistério público e da atuação em outros cargos como funcionário, experimentou uma mobilidade social aos moldes do que Antônio Candido chamou de "funcionário do Império" (2002). Sua trajetória evidencia certa maleabilidade social no Brasil oitocentista, mesmo que acentuadamente diminuta, com espaço para ascensão social de um homem "sem passado", mas com muitas habilidades sociais, por

\footnotetext{
${ }^{4}$ Lembrando que foram criadas apenas duas províncias durante o período imperial, a do Amazonas (desmembrada do Grão-Pará pela lei 582, de 5 de setembro de 1850) e a do Paraná (lei 704 de 29 de agosto de 1853).

${ }^{5}$ Agostinho Leão e Francisco Negrão foram autores de genealogias e dicionários paranaenses e compõem a "geração que, em 1900, fundou o Instituto Histórico e Geográfico do Paraná" (Westphalem, 2004, p. 13).
} 
meio da carreira no serviço público - mais especificamente como professor público de primeiras letras.

Em 1836, o nome do mestre figurava numa lista de jurados do termo de Curitiba ${ }^{6} \mathrm{e}$ em ofício de outubro de 1848, o professor Brandão consultou a presidência da província sobre a compatibilidade entre os empregos de professor e vereador ${ }^{7}$. Recebeu resposta afirmativa. A incompatibilidade estava apenas entre os cargos de vereador e Juiz de Paz, ${ }^{8}$ muito provavelmente, devido ao movimento de separação dos poderes executivo, legislativo e judiciário que se ensaiava nas instituições imperiais. Depois disso, só temos indícios da atuação do professor, além do magistério, como Juiz de Paz ${ }^{9}$. Francisco Negrão e Ermelino Agostinho de Leão, em publicações de 1926, destacam sua longa e prestigiada atuação no cargo:

Foi Juiz de Paz em Curityba por espaço de 50 annos e com tal criterio se houve nesse cargo que, era eleito, sem solução de continuidade, apezar de se terem revezado no poder por varias vezes os dous Partidos Politicos do Imperio. Todos o queriam, todos o prestigiavam. [...] Como Juiz de Paz servia de medianeiro entre as duas partes contendoras, que no geral se separavam satisfeitas e acordadas. Nas audiencias comparecia sempre trajando a rigor, com seu bastão de mando e a brilhante facha de Juiz a tiracolo, como insignias de sua autoridade. (NEGRÃO, 1926, p. 131, grifos nossos)

[...] Exercia a função com garbo, trajando-se a rigor quando ia a audiencias, empunhando a vara emblematica e trazendo a tiracolo a faixa auri-verde do cargo. (LEÃO, 1926, p. 953)

O "traje a rigor", a "vara" ou "bastão" de mando e a "faixa auri-verde", enfim, os símbolos de sua autoridade, são destacados nas duas descrições, e parecem ter sido cultivados pelo professor quando atuava como Juiz de Paz, vestindo um figurino paramentado composto por símbolos do Estado monárquico, ao qual ele já havia feito manifestações de estima. A despeito de se tratar de um cargo não remunerado, o professor exerceu a função por mais de 50 anos. A dedicação tão prolongada (o dobro do tempo que se dedicou ao magistério) indicia a popularidade de Baptista Brandão para ser sucessivamente reeleito e o grande apreço do próprio sujeito pelo trabalho como Juiz de Paz. No magistério, ele foi bastante atuante na reivindicação de recebimento de gratificações e na busca de aumento dos ordenados dos professores de primeiras letras e, mesmo assim, dedicou-se gratuitamente à judicatura de paz.

${ }^{6}$ Lista de jurados do termo de Curytiba. 27 de abril de 1836. "Série Manuscritos. Ofícios diversos de Curitiba 1835-37". Localização: CO 1002

7 Ofício manuscrito do professor de primeiras letras João Baptista Brandão de Proença dirigido ao Exmo presidente da Província de São Paulo em 04 de outubro de 1848. Lata: "Série Manuscritos. Ofícios diversos de Curitiba 1845-51". Localização: CO 1005. AESP.

8 Ofício manuscrito anexo ao do professor de primeiras letras João Baptista Brandão de Proença de 04 de outubro de 1848. Sem data. Sem autor. Lata: "Série Manuscritos. Ofícios diversos de Curitiba 1845-51". Localização: CO 1005. AESP.

9 O posto de Juiz de Paz, criado em 1827, foi, de acordo com Flory (1986) uma vitória liberal, ao lado da criação do júri, frente à centralização do primeiro reinado: "cujos membros, anualmente alistados entre os eleitores locais, julgavam devassas gerais, devassas especiais e querelas feitas em processo público e oral". Grinberg (2008), a partir da chave de leitura de Thomas Flory (1986), considera que o posto de Juiz de Paz e o Júri representavam "o fortalecimento do poder local e [...] [a] maior autonomia de distritos e províncias, sendo por isso combatidos pelos conservadores". Com a reforma do judiciário de 1841, "os juízes de paz eleitos tiveram boa parte de suas atribuições transferidas para os juízes municipais e chefes de polícia, (doravante nomeados diretamente pelo imperador)" (Grinberg, 2008, p. 452). 
Francisco Negrão dedica seis páginas ao que ele denomina Título Brandão de Proença na Genealogia Paranaense (NEGRÃO, 1926, p. 129-134). "Título", na Genealogia, é uma denominação honorífica de uma das famílias tradicionais paranaenses. Dentre os professores de primeiras letras da primeira metade do Século XIX, o professor João Baptista Brandão de Proença é o único ${ }^{10}$ fundador de uma família paranaense eleito por Francisco Negrão para fazer parte da obra. Os critérios de seleção das famílias foram políticos, Negrão "preferiu concentrar o poder dentro de famílias com ênfase na região do planalto de Curitiba" (OLIVEIRA, 2003, p. 31) com diversidade de ofícios e cargos políticos.

Francisco Negrão destaca a atuação do mestre apoiando-se, sobretudo, nas atas da Câmara de Curitiba, da qual seu avô, João de Souza Dias Negrão foi vereador, contemporâneo de Brandão. A preocupação de Francisco Negrão, e dos demais paranistas ${ }^{11}$, era construir uma identidade para os paranaenses. De acordo com Oliveira (2003), o caminho por ele escolhido foi o de "procura[r] sempre ver a existência de uma comunidade no Paraná" resgatando "as estruturas de parentesco enraizadas neste território e que adquirem uma consciência de classe, da necessidade de autonomia do Paraná, principalmente em relação a São Paulo" (OLIVEIRA, 2003, p. 31).

Negrão conferiu a João Baptista Brandão de Proença uma posição de proeminência como mestre de primeiras letras, não por ter sido o primeiro de Curitiba, mas por ser o mestre em exercício à época da emancipação da província e ter sido um dos responsáveis pela instrução primária das gerações que construíram a Província do Paraná. Esta geração de professores que começou a atuar às vésperas da emancipação teve, como característica comum, corpos discentes heterogêneos compostos por muitos personagens que, posteriormente, tiveram intensa atuação política, social e cultural na Província do Paraná. Tratava-se de uma região pouco povoada à época e com uma reduzida população letrada, deste modo as escolas de primeiras letras ajudaram a compor desde o quadro de funcionários públicos, passando por cargos políticos, até artistas.

Houve convivência do pai do genealogista e de seu avô João de Souza Dias Negrão com o mestre e o irmão de Proença, Francisco de Paula Guimarães. Como vereadores, estiveram presentes à sessão na qual foi lida a petição do professor para intervenção da Câmara junto ao presidente da Província de São Paulo "reiterando as solicitações que tem dirigido ao Governo de S. Paulo, solicitando utensílios para sua aula, a fim de a pôr com o methodo Lancasteriano; sua petição foi lida em sessão ordinária da Camara, de 14 de julho de 1837" (B. A. M. C, v. 49, 1837-1838, p. 22-23 apud NEGRÃO, 1926, p. 130).

Dez anos mais tarde, João Baptista Brandão de Proença foi professor do pai do autor da genealogia:

[..] foram publicamente examinados em leitura, escripta, teoria e pratica d'Arithmetica até proporções inclusive e princípios de moral christã e da Doutrina da

\footnotetext{
10 Uma rápida menção é feita ao padre Albino no título Marques da Cunha, uma vez que seu irmão Euristeu José da Cruz, casou-se com a filha de José Marques da Cunha e teve, em 1855, um filho batizado Albino da Cruz, afilhado do padre Albino José da Cruz (Negrão, 1926, V. V, p. 403).

11 De acordo com Camargo (2007), "o Paranismo [...] é resultado do ambiente formado desde as últimas décadas do século XIX para a edificação de uma identidade no Paraná. Foi definido oficialmente em termos estético-ideológicos por Romário Martins em 1927 e tem uma curta mas ativa presença institucional até o encerramento da circulação da revista llustração Paranaense, em 1931. Seus efeitos, porém, foram a tal ponto naturalizados no imaginário paranaense que podem ser notados ainda hoje em muitas formulações oficiais ou individuais (Camargo, 2007, p.14).
} 
Religião do Estado os alunos João de Sousa Dias Negrão Junior [...], os quais sahirão plenamente aprovados ${ }^{12}[\ldots]$

Assim, as próprias experiências, memórias e relações sociais de seus ascendentes funcionaram como critérios para Francisco Negrão na escolha dos personagens de sua genealogia.

Os descendentes de João Baptista Brandão de Proença também foram letrados atuantes em cargos públicos, políticos, militar e na docência. A família teve, pelo menos, cinco professores, entre os quais um genro lente de latim, uma nora professora pública, um sobrinho-neto professor público e diretor de colégio, uma sobrinha-neta professora normalista, e, por fim, outro sobrinho-neto ${ }^{13} \mathrm{com}$ uma trajetória mais diversificada na docência como normalista, professor público em Paranaguá e Curitiba e proprietário de colégio conceituado em Curitiba.

O professor João Baptista Brandão de Proença "manejava variadas práticas e partilhava dos códigos da cultura letrada" (SCHUELER, 2008, p. 11). Além da autoria do "hino da emancipação", já destacado, escreveu um "Compendio de Grammatica Portuguesa". Temos notícia da nomeação de uma comissão para sua análise em dezembro de $1854^{14}$. Não encontramos, no entanto, o compêndio, nem indícios de que tenha sido adotado. Em cumprimento de ordem do primeiro presidente Zacarias Góes de Vasconcellos, ele elaborou também um parecer sobre "o ensino primário na província e a lei em vigor ${ }^{15 " . ~ E s t e ~ e ́ ~ o ~ o b j e t o ~ d o ~ p r o ́ x i m o ~ i t e m . ~}$

\section{O "parecer" como atestado de autoridade}

Em junho de 1854, cinco meses após a instalação da Província do Paraná, o professor foi instado pelo presidente, o Conselheiro Zacarias, a "expor [suas] ideas a respeito do ensino primario nesta província em relação as disposições da lei de instrução pública em vigor" (PROENÇA, 1979, p. 47). O manuscrito do professor Brandão, com sete páginas, foi publicado no Boletim do Arquivo do Paraná, em 1979, sob o título "O ensino primário em 1854". Trata-se de um título atribuído a posteriori. A publicação, 125 anos depois, traz também esta breve explicação sobre o texto:

12 Cópia da acta de exame de seus alumnos, que tiveram lugar no dia 4 de Desembro do anno proximo findo. Remitida inclusa à representação/ pedido de aumento do ordenado do professor João Baptista Brandão. 02 de janeiro de 1847. AESP. CO 1004. Grifos nossos.

${ }^{13}$ Conforme o amigo e compadre Francisco Negrão. As inserções profissionais e sociais, além dos laços de amizade e compadrio, parecem ter influenciado na opção do genealogista de incluir o "título Brandão de Proença" na obra.

14 Jornal O Dezenove de Dezembro, 30 de dezembro de 1854, Publicação dos "Actos da Presidência da Província do Paraná", p. 03

${ }^{15}$ Lei no 34 de 16 de março de 1846 - a lei paulista ainda vigorava na nova província, visto que esta ainda não havia constituído o seu próprio ordenamento jurídico. 


\section{João Baptista Brandão de Proença, um} dos primeiros professores do Parană, envia ao Presidente da Provincia o seu parecer sobre a situação do Ensino Prima rio no Brasil e na Provincia no ano de 1854:

Figura 1 - Epígrafe de "PROENÇA, João Baptista Brandão de. O ensino primário em 1854.

Fonte: Boletim do Arquivo do Paraná. Curitiba, Departamento Estadual de Arquivo e Microfilmagem do Paraná, № 4, 1979, p. 47.

Além do título a posteriori, a publicação do "Boletim do Arquivo do Paraná" classificou o texto como um "parecer sobre a situação do Ensino Primário". Deste modo, contribuiu para legitimação de João Baptista Brandão de Proença como um especialista em instrução pública, alguém com saberes legítimos para emitir um parecer. Mais uma vez, o professor foi colocado num lugar de proeminência como "um dos primeiros professores do Paraná".

O texto foi construído dentro das características da diplomática das comunicações oficiais do Império brasileiro: o autor informava o que estava cumprindo, no caso uma ordem do presidente da província, e ressaltava em si mesmo "a falta de precisas habilitações para tratar de matéria tão transcendente" (BRANDÃO, 1979, p. 47). A seguir enfatizava a importância da instrução e, ao mesmo tempo, exaltava a ilustração de seu destinatário, o presidente da província. Destacava que a "instrução primária garantida como está pela Constituição política do Imperio, tem-se constituído uma divida do Estado, e uma obrigação comum a todos os cidadãos" (BRANDÃO, 1979, p. 47). O conhecimento dos textos legais foi uma habilidade marcante desse professor de primeiras letras e o destaque dado à instrução como direito/obrigação era importante para a argumentação que ele desenvolveu.

Prosseguiu demonstrando conhecimentos acerca de experiências bem-sucedidas de outros países na instrução, leia-se países da Europa - Alemanha, Bélgica e Prússia atribuindo o seu sucesso a "sabias medidas legislativas", sobretudo à lei de "obrigatoriedade do ensino". Passou então a defender a criação de uma lei deste tipo no Brasil, considerando "preferível alguma severidade da lei, do que ver criar-se como se crião por esses lugares centraes, moços de belíssima aparência, robustos e vigorosos analphabetos completamente" (BRANDÃO, 1979, p. 48). O professor, ao propor a lei, estabelecia o perímetro e a idade da obrigatoriedade escolar, prevendo o direito de as famílias darem a "instrução religiosa e intellectual particularmente em suas casas, ou em aulas particulares, legalmente autorizadas" (BRANDÃO, 1979, p. 48).

Fez considerações sobre a lei provincial de São Paulo de 16 de março de 1846, a qual avaliava como tendo "disposições [...] muito apropriadas", mas que "nas actuaes circunstancias d'esta nascente provincia [...] não poderá ser adaptada sem reforma de algumas de suas disposições" (BRANDÃO, 1979, p. 48-49). As reformas sugeridas pelo professor concentravam-se em um único tema: os vencimentos. Proença criticava o "art" 15 da lei n 28 de 16 de Março de 1847" que dispunha: 
Art. 15. Os ordenados e gratificações marcados nos artigos quinze, dezesseis, e dezessete da lei provincial numero trinta e quatro de desesseis de março de mil oitocentos quarenta e seis, competem unicamente aos professores, e professoras providos em virtude da mesma, e não aos anteriores, que gozarão dos benefícios das leis de sua creação ficando assim declarada a referida da lei ${ }^{16}$ (grifos nossos).

O professor, que recebia vencimentos de $360 \$ 000^{17}$ réis anuais, reclamava da exclusão dos professores que, como ele, foram providos de acordo com leis anteriores. Mais uma vez, o professor demonstrava estar atento à dinâmica legislativa e, baseando-se na sua experiência e no conhecimento das leis, considerava que o artigo acima:

[...] resultou uma grande injustiça aos professores providos em virtude da lei de 15 de outubro de 1827, não so porque por suas antiguidades e serviços prestados à instrucção tenhão senão maior ao menos igual direito a essas vantagens, como porque as matérias de ensino exigidas pelo artigo 1으 da lei de 16 de Março de 1846 são as mesmas, que exige a lei de 15 de outubro de 1827. (BRANDÃO, 1979, p. 49)

O conhecimento e a proposição de leis para resolução dos problemas da instrução pública sugerem a confiança do professor na via legal para resolução dos problemas. Nóvoa destaca que o projeto de incorporação dos professores ao funcionalismo "deve ser encarado como uma vontade partilhada do Estado e do corpo docente" (NÓVOA, 1995, p. 174). Nesse sentido, há tensões e negociações para conciliar os diferentes interesses. João Baptista Brandão de Proença, um dos professores nomeados em virtude da lei de 1827, sentiu-se prejudicado pela lei paulista de março de 1847 e quando teve a chance, expôs o seu descontentamento. Cabe acionarmos as considerações de E. P. Thompson sobre a lei. Para este autor:

\begin{abstract}
A maioria dos homens tem um forte senso de justiça, pelo menos em relação a seus próprios interesses. Se é a lei manifestamente parcial e injusta, não vai mascarar nada, legitimar nada, contribuir em nada para a hegemonia de classe alguma. A condição prévia para a eficácia da lei em sua condição ideológica é de que mostre uma independência frente a manipulações flagrantes e pareça justa. Não conseguirá parecê-lo sem preservar sua lógica e critérios próprios de igualdade; na verdade às vezes sendo realmente justa. (THOMPSON, 1987, p. 354)
\end{abstract}

Desta vez, a lei não se legitimou, pois foi considerada injusta, não só por não ter previsto vantagens pela antiguidade no cargo, mas principalmente porque os professores mais antigos recebiam salários menores que professores mais novos. O professor insistiu na reforma legal para se fazer justiça e melhorar a instrução, recorrendo ao discurso de

\footnotetext{
${ }_{16}$ Artigo 15 da Lei no 28 de 16 de março de 1847. Os artigos 15, 16 e 17 da Lei no 34 de março de 1846 fixavam ordenados de quatrocentos a quinhentos mil réis nas cidades e de duzentos e cincoenta á trezentos mil réis nas demais localidades; previa gratificação para as escolas frequentadas por mais de 20 alunos "efetivamente", de "quatro mil réis por cada aluno que exceder o dito numero"; e o direito à aposentadoria àqueles que tivessem exercido o magistério por vinte e cinco anos "com todo o ordenado que vencerem ao tempo da aposentadoria" com possibilidade de continuar por mais cinco anos e receber "mais a décima parte" e aposentadorias "proporcionais" para os que se tivessem servido por mais de dez anos e ficassem impossibilitados de continuar.

Disponível em http://www.al.sp.gov.br/repositorio/legislacao/lei/1847/lei\%20n.28,\%20de\%2016.03.1847.pdf

17 Decreto imperial de 07 de agosto de 1832. Disponível em http://www.camara.gov.br/Internet/InfDoc/conteudo/colecoes/Legislacao/legimp-15/Legimp-15_5.pdf. http://www.camara.gov.br/Internet/InfDoc/conteudo/colecoes/Legislacao/legimp-15/Legimp-15_5.pdf. Acesso em 13 de fevereiro de 2012.
} 
autoridade de Degerando ${ }^{18}$, para quem "o magistério público [...] [era] uma espécie de sacerdócio civil".

[...] parece ser de justiça que os ordenados, que se tiverem de marcar possão não só remunerar o trabalho, a dedicação, a assiduidade a que são obrigados os professores da instrucção primaria, como se prestem á formação de um pecúlio para casos imprevistos. A consignação do máximo do ordenado que estabelece a lei, exclusivo das gratificações autorizadas pela mesma me parece ser suficiente para remunerar os trabalhos inerentes ao magisterio. (BRANDÃO, 1979, p. 49-50)

A estrutura do texto assemelha-se a de relatórios de inspetores da instrução pública, embora menos extenso. Pouco mais de um mês depois de Brandão de Proença enviar o seu "parecer" ao presidente, Zacarias apresentou o seu relatório na abertura da Assembleia legislativa provincial, em 15 de julho de 1854. Ao tratar do ramo da instrução pública, o presidente anunciava que:

Todas as corporações e funcionários, á quem ouvi acerca do estado da instrução na provincia, derão-me as mais desfavoráveis informações desse ramo do serviço publico, e assim parece ser, a vista de documentos que tive presentes ${ }^{19}$.

O relatório sugere que o presidente tivesse ouvido, e talvez solicitado, exposições a "respeito do ensino primário" e das "disposições da lei de instrução pública em vigor" a outros professores e sujeitos relacionados com a instrução pública. A abordagem de mais questões pelo presidente do que as apresentadas pelo professor indicia esta multiplicidade de vozes. Zacarias explicitou, ainda, que leu "o relatório de 10 de março de 1852 do inspector geral da instrucção de S. Paulo" (p. 18) e, possivelmente, apropriou-se do exemplo paulista.

Observemos os temas abordados pelo presidente Zacarias com o objetivo de compararmos com o "parecer" do professor João Baptista. O presidente informou sobre este "ramo do serviço público" em um texto dividido em três partes: a primeira versa sobre o ensino primário, a segunda sobre o ensino secundário e a terceira sobre o ensino privado. Na primeira parte, a que nos interessa, tece considerações sobre os seguintes "pontos": "10 Vencimentos dos professores", "20 Inpeccção", "3 Objetos e grãos do ensino", "4 Ensino Obrigatório", " $5^{\circ}$ Methodo a adoptar-se nas escolas"; "6º́neros de Alumnos essencial a existência d'aula" e "70 Escolas do Sexo Feminino".

É possível constatar correspondências entre o "parecer" do professor e o relatório do presidente. Os dois temas tratados pelo professor João Baptista Brandão de Proença são abordados por Zacarias. O tema ao qual o professor mais se dedica, os vencimentos, é primeiro no relatório do presidente e o teor é muito semelhante. O presidente utilizou argumentos diferentes daqueles do professor. Destacou o "absurdo" dos valores, comparando com a remuneração de outros ofícios. Só se referiu à legislação ao final quando apresentou a mesma proposta que Brandão de Proença, a de fixar os ordenados

18 O barão de Gérando é autor da obra Curso Normal para Professores de Primeiras Letras ou direções relativas à educação physica, moral e intelectual nas Escolas Primárias pelo Barão Degerando, impresso por ordem do Governo Provincial do Rio de Janeiro para uso dos professores. Nictheroy. Typographia Nicteroy de M.G. de S. Rego. Praça Municipal. 1839. 386p. e Apêndice de Leis Gerais e Provinciais (apud BASTOS, 1999, p. 241).

${ }^{19}$ Relatorio do Presidente da Provincia do Paraná o Conselheiro Zacarias de Góes e Vasconcellos na Abertura da Assembléa Legislativa Provincial em 15 de julho de 1854, p. 12, grifos nossos. 
no valor máximo previsto pela lei paulista, o que representava salários de $400 \$ 000$ a $500 \$ 00$ réis nas cidades, $300 \$ 000$ a $400 \$ 000$ nas vilas e $250 \$ 000$ a $300 \$ 000$ réis nas demais povoações.

Outro tema comum foi o ensino obrigatório. O professor se referiu às experiências de outros países e detalhou os meandros necessários para aprovação da lei e suas disposições (distâncias, idades). Já o presidente explorou uma simbologia que misturava elementos higienistas, cristãos e liberais:

\begin{abstract}
Obriga-se o povo á vacina, e ele obedece ou deve obedecer sem reparo, porque he hum meio de preservar-se de hum flagelo fatal.

Ora a intrucção primaria he, por assim dizer, huma vacina moral, que preserva o povo do peior de todos os flagelos conhecidos e por conhecer - a ignorância - das noções elementares, que nivela o homem ao bruto, e o torna matéria apta e azado instrumento para o roubo, para o assassinato, para a revolução, para todo mal, enfim.

A instrucccão primaria he mais: he huma espécie de baptismo com que o homem regenerado da crassa ignorância, em que nasce, efeitua verdadeiramente sua entrada na associação civil e no gozo dos direitos, e vantagens, que the são inherentes. (p. 17, grifos nossos)
\end{abstract}

Professor e presidente sugeriram o uso da "severidade" (BRANDÃO, 1979, p. 48) ou "obrigar-se o povo" (RELATÓRIO, 1854, p. 17) em virtude de um bem maior. No entanto, havia uma diferença significativa. Enquanto o professor via a instrução como meio para acabar com "a triste condição" dos "moços de belíssima aparência [..] analphabetos completos", o presidente a percebia como "vacina moral que preserva o povo do peior de todos os flagelos conhecidos e por conhecer - a ignorância". Ao identificar falta de instrução à ignorância, associava-a à aptidão para "roubo, assassinato, para a revolução, para todo mal, enfim".

Em síntese, os temas expostos pelo professor foram abordados no relatório do presidente da província, com argumentações diferentes para propostas semelhantes. E mais do que terem sido objeto de um relatório do representante maior do poder executivo na província, as considerações do professor de primeiras letras foram contempladas pelo poder legislativo: a assembleia provincial aprovou a obrigatoriedade do ensino, fixada pela "Lei Provincial n. 17 de 14 de setembro de 1854", e o aumento dos vencimentos com a "Lei $\mathrm{n}^{\circ} 21$ de 02 de março de 1857" - que fixou ordenados, significativamente, mais altos para os professores de primeiras letras da província do Paraná ( $800 \$ 000$ réis com gratificação de $200 \$ 000$ para as cadeiras das cidades e $600 \$ 000$ para vilas e outros lugares). É preciso esclarecer, no entanto, que a reivindicação salarial inscrita no parecer de 1854 não era uma novidade na pena de Baptista Brandão. Desdobraremos esta questão no item seguinte.

A trajetória do professor de primeiras letras permite apreender que, se por um lado, as suas práticas eram pautadas pelo cumprimento e sujeição à legislação, por outro, ele fez um uso tático (CERTEAU, 1994) do repertório que havia acumulado ao longo do magistério e de outros cargos político-administrativos para que seus interesses, ao mesmo tempo, individuais e coletivos fossem contemplados pela lei. 


\section{Os ordenados na trajetória do professor João Baptista Brandão de Proença e na constituição da docência na Província do Paraná}

Em janeiro de 1847, Brandão de Proença remeteu representação ${ }^{20}$ ao presidente da Província de São Paulo, na qual solicitava o aumento de seu ordenado, anexando as atas dos exames dos alunos aprovados, como um recurso utilizado por quem conhece bem a legislação para confirmar a "frequência certa" dos alunos e, mais do que isso, o bom aproveitamento com aprovação em exames. Em outubro daquele mesmo ano, reiterou o pedido ${ }^{21}$. Como explicitado anteriormente, a lei no 34 de 16 de março de 1846 criara uma distinção entre professores antigos e novos, desfavorecendo os primeiros. Se em 1854, o professor apelou para a equiparação, em 1847, preferiu requerer a gratificação prevista pela lei de 1827, segundo a qual:

Art. 10. Os Presidentes, em Conselho, ficam autorizados a conceder uma gratificação anual que não exceda à terça parte do ordenado, àqueles Professores, que por mais de doze anos de exercício não interrompido se tiverem distinguido por sua prudência, desvelos, grande número e aproveitamento de discípulos (Lei de 15 de outubro de 1827).

As premissas de que (1) o empregado público deve ser recompensado pelo seu trabalho, (2) o seu ordenado era escasso, (3) a vida havia encarecido na cidade de Curitiba convergiam para a conclusão de que ele tinha o direto à gratificação anual, visto que exercia as funções do emprego sem interrupção desde 1835 até aquele momento. Se as atas dos exames comprovando a frequência e aproveitamento dos alunos não haviam sido suficientes para concessão do aumento, o professor mudou de tática recorrendo às "circunstâncias peculiares da localidade" de "encarecimento dos víveres e mais gêneros de primeira necessidade". O professor não foi atendido no pleito.

Logo após a emancipação da Província do Paraná, encontramos um novo pedido do professor - uma das primeiras comunicações oficiais do arquivo do Paraná - citando e juntando cópias das suas tentativas anteriores junto à presidência da Província de São Paulo que, segundo o professor Brandão, haviam sido "esquecida[s] na Secretaria de Governo d'aquella Provincia por tão longo tempo". Mais uma vez, ele recorreu, na argumentação, às necessidades materiais, considerando que:

Sendo minimamente escasso o ordenado que ora percebo $(360 \$ 000)$ para subsistir e alimentar família; certamente não deixará $V$. Exa de atender á pretensão do Suplicante por ser, como é, fundada na lei e na justiça [...].

João Baptista Brandão de Proença. ${ }^{22}$

20 Ofício manuscrito do professor de primeiras letras João Baptista Brandão de Proença dirigido ao Exmo presidente da Província de São Paulo em 02 de janeiro de 1847. Lata: "Série Manuscritos. Ofícios diversos de Curitiba 1845-51". Localização: CO 1005. AESP. Esta representação é um dos documentos anexados pelo professor ao pedido que fez à Província do Paraná em 29 de dezembro de 1853, dez dias após a instalação da Província do Paraná.

${ }^{21}$ Requerimento do professor de primeiras letras João Baptista Brandão de Proença de gratificação prevista pela lei de 15 de outubro de 1827 dirigido ao presidente da Província de São Paulo. 22 de outubro de 1847. Anexo ao Requerimento do mesmo professor de 29 de dezembro de 1853 dirigido ao presidente da Província do Paraná. APPR. AP0001, p. 162 a 167 e p. 195 ou IIP1.6

22 Ofício manuscrito do professor de primeiras letras João Baptista Brandão de Proença dirigido ao Exmo presidente da Província do Paraná em 29 de dezembro de 1853. O deferimento do procurador Gonçalves Guimarães consta na margem do mesmo ofício com data de 30 de janeiro de 1854. APPR IIP1-6. 
O deferimento de pronto do governo da Província do Paraná é indício do novo lugar que o professor ocupava no cenário. O Procurador fiscal "Gonçaves Guimarãens" fundamentou-se na legislação concedendo a gratificação prevista pela lei de 1827 e não os ordenados de 1846, uma vez que os ordenados previstos por esta lei competiam apenas:

[...] aos Professores providos em virtude da mesma lei, ficando os anteriores gosando dos benefícios da Lei Geral de 15 de 8 bro de 1827 e tendo o suppe saptisfeito as exigências do art. 10 d'esta Lei: entendo que têm direito a uma gratificação anual não excedente a terça parte do seo ordenado. Cor ${ }^{\mathrm{a}}$. 30 de Janeiro de 1854. Glz Guimarães ${ }^{23}$.

Foi um longo e insistente percurso até garantir o direito previsto por lei de receber uma gratificação anual com a terça parte do ordenado: $120 \$ 000$ réis. Após conhecer todo este itinerário, é possível uma empatia maior frente à indignação do professor no "parecer" de 1854, ao que ele denominou "grande injustiça aos professores providos em virtude da lei geral de 15 de Outubro de 1827" (PROENÇA, 1979, p. 49). Contudo, a conquista ainda não se concretizara, o professor percorreu um caminho tortuoso para efetivar a gratificação, com recorrentes ofícios ${ }^{24}$ ao presidente solicitando, quase anualmente, que o pagamento fosse ordenado à tesouraria, características próprias de instituições em constituição onde as atribuições estão sendo organizadas.

A situação transformou-se expressivamente em 1857. No dia 22 de abril daquele ano, 50 dias após a promulgação do regulamento de 02 de março de $1857^{25}$, o professor enviou um ofício requerendo gozar das vantagens da referida lei:

\begin{abstract}
João Baptista Brandão de Proença, Professor publico da 1르 Cadeira de instrucção primaria d'esta Cidade não podendo subsistir com o ordenado que actualmente percebe, em rasão do encarecimento e subido preço á que tem chegado os gêneros de primeira necessidade, e julgando-se em circunstancias de obter as vantagens estabelecidas pela lei provincial de 2 de Março do corrente anno, e sendo o mais antigo Professor da Provincia em efectivo exercício, vem requerer a V. Ex ${ }^{\underline{a}}$ se digne de designar o Suppe no numero dos Professores vitalícios que tem(?) de gosar dos favores da referida lei, marcando-lhe o ordenado de $800 \$ 00$ annuaes e a gratificação de $200 \$ 000$, ou somente o ordenado, ficando o suppe com as gratificações que ora percebe, e á que fez jus pelos serviços que tem prestado no longo espaço de 22 annos de magisterio, e bem certo dos sentimentos de recta justiça que caracterisão a $\mathrm{V}$. Ex $x^{\mathrm{a}}$.

P. a V. Ex $x^{a}$ se digne de deferi-lo favoravelmente, de cuja graça

E. R. $\mathrm{Me}^{26}$

Cidade de Curityba 22 d'Abril de $1857^{27}$.
\end{abstract}

${ }^{23}$ Deferimento do procurador Gonçalves Guimarães na margem esquerda do Ofício manuscrito do professor de primeiras letras João Baptista Brandão de Proença dirigido ao Exmo presidente da Província do Paraná em 29 de dezembro de 1853. 30 de janeiro de 1854. APPR IIP1-6.

24 Ofícios/requerimentos de pagamento de gratificação do professor João Baptista Brandão de Proença para o presidente da Província do Paraná (para que este ordenasse à Tesouraria o pagamento da gratificação concedida). 28 de março de 1855; 17 de setembro de 1855; 16 de junho de 1857. AP0022, p. 09 e 29.

${ }^{25}$ Art. $8^{\circ}$ - Os professores que forem providos vitaliciamente com as habilitações legais perceberão, para as cidades o ordenado de $800 \$ 000$ réis e gratificação de $200 \$ 000$ réis e para as vilas e outros lugares 0 ordenado de $600 \$ 000$ réis e $200 \$ 000$ réis de gratificação. / Art. 9o - Logo que for publicada a presente lei, o Governo designará quais dos atuais professores vitalícios estão no caso de gozar dos favores dela (MIGUEL, 2004, p. 49).

${ }^{26} \mathrm{E} R \mathrm{Me}$ : Esperando receber mercê.

${ }^{27}$ Requerimento do professor João Baptista Brandão de Proença ao presidente da província. 22 de abril de 
Trata-se da lei sobre a qual aventamos a hipótese de ter incorporado a reivindicação do professor elaborada no "parecer" de 1854. O "mais antigo Professor da Provincia em efectivo exercício" muito possivelmente vinha acompanhando os debates na assembleia e esperava a aprovação de uma lei que aumentasse os ordenados. Quando a lei foi criada, manifestou-se fazendo uma nova tentativa de aumento do salário. O professor recebeu o ordenado de $360 \$ 000$ anuais de 1835 (ano em que provido) a 1854, ano em que conseguiu a gratificação de $1 / 3$ dos vencimentos recebendo mais $120 \$ 000$ anuais, o que somava $480 \$ 000$. Um mês após a lei de março de 1857 , o sagaz seguidor das leis - na dupla acepção, como aquele que acompanha as últimas notícias e cumpre a norma - João Baptista Brandão de Proença remeteu ofício solicitando aumento. Os salários da nova lei com a gratificação $(1000 \$ 000)$ somavam mais do que o dobro do que ele recebia até então (480\$000 com a gratificação), uma transformação bastante significativa.

Embora não tenhamos localizado uma resposta do governo provincial, o requerimento de aposentadoria "com ordenado que actualmente percebe" 28 e a concessão da aposentadoria 29 "com ordenado de $800 \$ 00$ " indiciam que o professor logrou êxito na sua segunda tentativa de aumento de ordenado após a emancipação da Província do Paraná. O professor solicitou sua aposentadoria (apenas!) três dias após completar 25 anos de magistério, citando a lei no 51 de 16 de fevereiro de 1859 .

Em seu primeiro artigo, a lei ํㅜ 51 declarava que:

Art. $1^{\circ}$ - Os antigos professores e professoras vitalícios, que foram compreendidos nos favores da lei no 21 , de março de 1857, por designação do Governo, ou por haverem feito exame de capacidade, terão direito à aposentadoria ou jubilação com o ordenado que ora percebem, uma vez que completem o tempo de vinte cinco anos, contados da data da posse ou exercício anterior à supracitada lei. (MIGUEL, 2004, p. 103, grifos nossos)

Talvez não seja apenas uma coincidência o fato da lei apresentar os termos "antigos professores" e não apenas "professores vitalícios" como o fez a lei oㅡ 21. No requerimento, de 22 de abril de 1857 citado anteriormente, o professor se autodenominava o "mais antigo professor". Em 04 de janeiro de 1859, Brandão de Proença solicitara um substituto, visto que ia tomar assento na Assembleia Legislativa da Província do Paraná compondo a legislatura provincial do biênio 1858/59. O professor foi um dos deputados da assembleia provincial que aprovou a lei o 51 (NICOLAS, 1954, p. 79), regulamentando a aposentadoria dos professores de primeiras letras e garantido aos "antigos professores" a manutenção do ordenado.

Com a emancipação da província, o professor Brandão de Proença passou das ações táticas a um lugar estratégico que lhe permitiu agir, "um lugar suscetível de ser concebido como próprio" (CERTEAU, 1994), e se assegurar de conquistas, como a aposentadoria com um ordenado que equivalia a quase o dobro do que receberia se a região continuasse sendo uma comarca da Província de São Paulo. A mudança políticoadministrativa afetou significantemente a existência deste professor e a sua experiência

1857. APPR. AP0022, p. 29.

28 Petição de jubilação do professor dirigida ao inspector geral da instrucção Publica. 04 de agosto de 1860. APPR, AP0022.

${ }^{29}$ Concede aposentadoria ao professor com salário de $800 \$ 000$ réis. $1^{\circ}$ de setembro de 1860 . APPR, códice 0951, p. 27. 
indicia lugares político-sociais acessíveis aos professores de primeiras letras no século XIX. As batalhas individuais que estes sujeitos travaram para conquistar benefícios como funcionários públicos foram, lentamente, fazendo-se presentes na legislação.

Os vencimentos foram fixados pelo "Regulamento de 08 de abril de 1857 da Província do Paraná" nos valores de $800 \$ 000$ e $1000 \$ 000$ réis, respectivamente, nas escolas primárias de $1^{\underline{a}}$ e $2^{\underline{a}}$ ordem das cidades, com gratificação de $200 \$ 000$ réis para a primeira e de $400 \$ 000$ para a segunda. Nas vilas e freguesias, os vencimentos seriam de $600 \$ 000$ réis e a gratificação de $200 \$ 000$. Disputas referentes aos vencimentos dos professores podem ser interpretadas no diálogo com as considerações de E. P. Thompson (1998) sobre a lei. Para o autor a lei é mais do que a expressão dos interesses das classes dominantes. Trata de regras em relação com a vida social que apresentam uma lógica interna, específica, técnica e, embora, geralmente, mantenham-se do lado mais forte, também são acionadas pelos dominados.

Se nos anos seguintes à emancipação paranaense verificamos uma valorização da profissão por meio do aumento dos salários, a partir da segunda metade da década de 1860, a tendência se inverteu com diminuição dos ordenados por meio de descontos. 0 trecho do relatório do inspetor da instrução pública em 1869 denuncia que:

[...] o poder legislativo tem, nestes últimos annos, cerceado os ordenados dos
professores, deduzindo dez por cento deles". Se sou severo em punil-os quando
infringem a lei sou justo em reclamar aquillo a que elles tem direito e exige a propria
conveniência do serviço. Se o empregado publico, em geral, deve estar
completamente resguardado das primeiras urgencias da vida, o professor com
maior razão deve estar acobertado dos botes da necessidade. Não insto para que
se Ihes dê vencimentos pingues, porem desejo que se lhes forneça meios de
satisfazer as primeiras necessidades da vida. Aquelle que é encarregado de
transmitir á mocidade as principaes luzes do saber é digno de alta consideração, a
qual jamais poderá sustentar, nem mesmo perante os seus alumnos, se forçado a
permanecer em uma completa indigencia. Confio por tanto que o poder legislativo,
reflectindo nas razões que venho de expor, bem longe de, desta vez, cercear os
vencimentos dos professores, Ihes dê o estipulado no citado regulamento, maximo
achando-se hoje a província com seu estado de finanças em um pé mais lisongeiro
que o passado. Como muito bem diz o illustrado conselheiro Liberato Barroso, não
nos fica bem fazermos de pobres e timeratos em materia de educação, quando
somos generosos e pródigos para tudo o mais, e muitas vezes fora de proposito ${ }^{30}$.

A lei não foi uma garantia de melhores ordenados para todos os professores de primeiras letras da Província do Paraná. O próprio poder legislativo acionou mecanismos para que o governo despendesse menos com os vencimentos. A luta passou a ser pela garantia de que vigorassem os salários previstos pelo regulamento de 1857. Nesse sentido, é interessante destacar o posicionamento público do Inspetor Ernesto Francisco de Lima Santos e a insinuação de que o governo provincial era acanhado e se fazia "pobre" na educação e esbanjava em "tudo o mais". Tal passagem pode ser interpretada como pista de que a preocupação com a Instrução Pública não ocupava lugar de destaque entre os negócios da província. No ano seguinte, $1870^{31}$, a polêmica permaneceu. O presidente

\footnotetext{
${ }^{30}$ Relatório oficial do Inspetor da Instrução Pública da província do Paraná Ernesto Francisco de Lima Santos de 06/03/1869. Anexo ao Relatório oficial do presidente Antonio Augusto da Fonseca. 06/04/1869

${ }^{31}$ Relatorio apresentado a Assembleia Legislativa do Paraná na Abertura da 1aㅗ sessão da 9aㅗ legislatura pelo presidente, o illustríssimo e excelentíssimo senhor dr. Antonio Luiz Affonso de Carvalho, no dia 15 de fevereiro de 1870. Curityba, Typ. De Candido Martins Lopes, 1870.
} 
Antonio Luiz Affonso de Carvalho referiu-se a petições dos próprios professores solicitando o pagamento do salário previsto pelo regulamento de 1857, mas preferiu levar a questão à assembleia para não abrir um precedente perigoso.

Entre 1847 e 1859, o professor Baptista Brandão se utilizou da lei e do seu lugar de poder para aumentar seu salário. Dez anos mais tarde, outros mestres enfrentavam batalhas - já não mais individuais, como indicia a petição de 1870 - para fazer valer um direito previsto pela lei, mas não cumprido pelo governo.

\section{Método mútuo na $5^{\mathrm{a}}$ Comarca e Materialidade da escola e do magistério}

O conhecimento da legislação também foi acionado por João Baptista Brandão de Proença, único professor pelo método Lancaster da Província do Paraná, ao assumir sua cadeira em 1835. Naquele momento, o professor procurou, por meio do cumprimento dos dispositivos legais, assegurar melhores condições materiais para o exercício do magistério.

Ao acompanhar a "história da divulgação, institucionalização e crise do sistema de ensino mútuo na Província de Minas Gerais", Faria Filho e Rosa (1999) interpretam a lei de 15 de outubro de 1827 como "a principal estratégia de divulgação e de expansão do método de ensino mútuo no país" (FARIA FILHO \& ROSA, 1999, p. 183). Na lei, o ensino mútuo é objeto dos seguintes artigos:

Art. 4o As escolas serão do ensino mútuo nas capitais das províncias; e serão também nas cidades, vilas e lugares populosos delas, em que for possível estabelecerem-se.

Art. 5o Para as escolas do ensino mútuo se aplicarão os edifícios, que couberem com a suficiência nos lugares delas, arranjando-se com os utensílios necessários à custa da Fazenda Pública e os Professores que não tiverem a necessária instrução deste ensino, irão instruir-se em curto prazo e à custa dos seus ordenados nas escolas das capitais.

Art. 15. Estas escolas serão regidas pelos estatutos atuais se não se opuserem a presente lei; os castigos serão os praticados pelo método Lancaster.

Após retomar os artigos da lei, retornemos à experiência docente de Brandão de Proença. Em novembro do primeiro ano na regência da cadeira, o professor dirigiu ofício ao vice-presidente da província buscando saber se a Igreja inacabada São Francisco de Paula pertencia a alguma Irmandade ou era dirigida por alguma pessoa, além do Tenente Ricardo Lustoza, responsável pela guarda das chaves ${ }^{32}$. Na mesma data, o professor fez a seguinte solicitação ao prefeito da Vila de Curitiba, Jozé Borges de Macedo:

Achando-me encarregado da direção da Aula de Primeiras Letras desta Villa e
regendo a mesma cadeira com o numero já em principio de sessenta e quatro
alunos, e proxima a admissão de maior numero que deve concorrer em rasão da
população d'esta mesma Villa; me vejo privado de, com franqueza, dar-lhes as
precisas liçõens por falta de espaço na Casa que pude obter para este fim, sem que
possa encontrar outra com as proporçõens exigidas, a exceção de uma bôa,
decente e grande sala que serve de Consistório da comessada Igreja de Sam
Francisco de Paula, Igreja que se axa em completo abandono, e suas chaves
entregues ao Tenente Ricardo Lustoza de Andrade, q. nada mais faz que guarda--
las, não havendo a menor esperança da conclusão da dita obra, por causa do
falecimento do devoto (?) que fervoroso a promovia; por isso desejava que, sendo

32 Ofício manuscrito do professor de primeiras letras João Baptista Brandão de Proença dirigido ao Exmo Vice-presidente da Província de São Paulo em 03 de novembro de 1835. Lata: "Série Manuscritos. Ofícios diversos de Curitiba. 1835-37". Localização: CO 1002. AESP. 
possível, Va $\mathrm{Ex}^{\mathrm{a}}$ mandasse a aquele depositario das chaves me entregasse a daquella sala para ali continuar nas liçõens a que estou encarregado [...]. ${ }^{33}$

O prefeito Jozé Borges de Macedo respondeu, em 04 de janeiro de $1836^{34}$, que o Tenente Lustoza "animado de sentimentos philantrópicos, em beneficio da mocidade desta mesma $\mathrm{V}^{\mathrm{a}}$, as entregou [as chaves] na qualidade de Thesoureiro da mesma Igreja".

No ofício de solicitação ao prefeito, o professor Brandão distinguiu as ações de dirigir uma Aula e reger a cadeira de primeiras letras, para em seguida informar que era responsável por ambas. A administração, a regência, entre outras atribuições constituíam o "ser professor", tais como conseguir alunos e providenciar o local para a realização das aulas - objetivo central da solicitação. O professor justificava o pedido do consistório da igreja demonstrando conhecimento sobre as "proporçõens exigidas" de uma "bôa, decente e grande sala" para dar "as precisas liçõens". Outros indícios da trajetória do professor permitem associar tais proporções exigidas a orientações relativas ao método lancasteriano. Em dezembro do mesmo ano de 1835, ele dirigiu um ofício ao presidente da Província de São Paulo, discriminando os utensílios necessários para o ensino pelo método lancasteriano:

\begin{abstract}
Em observancia ao Officio de Vํㅡㄹ $x^{\underline{a}}$ datado em 18 de Novembro próximo passado, em que V. Ex ${ }^{\underline{a}}$ me ordena declare os utencilios que he mister para por em execução a instrução pelo methodo Lancasteriano e em seu cumprimento declaro, que me é necessario cento e sincoenta Lousas, cem Traslados, sessenta Tinteiros e Areeiros, cento e sincoenta Lapis para escrever nas Lousas, oito semicírculos de ferro, desesseis bancos, uma Mesa, quanto aos bancos e Mesa se podem fasêr n'esta Villa, assim como oito Telégraphos e uma pedra para as diferentes lições em Arithmetica, e assim mais é necessário ser remetido Alphabetos e Livros de soletrar. Relativamente ao que se tem de fasêr nesta Villa, isto é bancos, Mesa, Telégraphos, e finalmente $\mathrm{o}$ arranjo da Aula, rogo que $\mathrm{V}^{\mathrm{a}} \mathrm{Ex}^{\mathrm{a}}$ que providencie para que pela Colectoria d'esta mesma Villa ou por alguma outra repartição se me forneça os meios pecuniários para pagamento de semelhantes obras, e afim de se mo não obstar inconvenientes. Deos a Vaㅡ Ex ${ }^{\underline{a}}$ guarde por muitos anos. Villa de Curytiba 14 de Dezembro de 1835.

Ilmo e Exm은 Sno Vice Presidente

D'esta Provincia de S. Paulo

O Professor João Baptista Brandám de Proença. ${ }^{35}$
\end{abstract}

Nesse ofício, o professor demonstrava conhecimentos acerca dos materiais necessários à aplicação do método mútuo, sinal de que além do repertório legal e políticoadministrativo, o professor acumulava também um repertório pedagógico: conhecia o método mútuo, era capaz de discriminar os materiais necessários para a sua aplicação e quase 20 anos depois desse pedido, conforme exposto anteriormente, o professor citara Degerando, autor de uma das obras de referência traduzidas para o português sobre 0 método (BASTOS, 1998).

33 Ofício manuscrito do professor de primeiras letras João Baptista Brandão de Proença dirigido ao Exmo Prefeito da Villa de Curityba em 03 de novembro de 1835. Lata: "Série Manuscritos Ofícios diversos de Curitiba 1835-37". Localização: CO 1002. AESP.

${ }^{34}$ Ofício manuscrito do prefeito Jozé Borges Macedo da Villa de Curityba dirigido ao professor de primeiras letras João Baptista Brandão de Proença. Lata: "Série Manuscritos. Ofícios diversos de Curitiba 1835-37". Localização: CO 1002. AESP.

35 Ofício manuscrito do professor de primeiras letras João Baptista Brandão de Proença dirigido ao Exmo vice-presidente da Província de São Paulo em 14 de dezembro de 1835. Lata: "Série Manuscritos. Ofícios diversos de Curitiba 1835-37". Localização: CO 1002. AESP. 
A sua trajetória (e a de outros mestres que atuaram durante o segundo quartel do Oitocentos) permite perceber que nem sempre foi possível adotar o método em razão da falta de materiais e prédios adequados à sua aplicação. Inácio (2005) ao estudar o caso da escola de primeiras letras de Diamantina, acompanhou as tentativas do professor público Joaquim Zacharias Pacheco que por mais de sete anos trocou correspondências com o governo provincial solicitando casa e utensílios necessários. $O$ caso de Diamantina parece não ter sido único. Em Curitiba, dois anos antes de o mestre Brandão de Proença iniciarse no magistério, o professor público Firmino Ferreira dos Santos ${ }^{36}$ enviara um ofício ${ }^{37}$ aos "Membros da Camara Municipal" informando que havia feito exame para adoção do método, mas não o fazia por falta de utensílios. No ano seguinte, em ofício que acompanhou o seu mapa de 11 de março de 1834, o professor não fez referência alguma ao método mútuo. Naquele mesmo ano, abandonou o magistério e findou sua breve tentativa de reger uma escola pelo método Lancaster.

O professor Brandão de Proença foi mais insistente que o seu antecessor e começou sua empreitada buscando os materiais necessários para abertura de sua aula pelo método Lancaster no mesmo ano em que foi provido, 1835. A troca de ofícios entre o professor, a câmara da Vila de Curitiba e a presidência da província estende-se até 1838. Em ofício da Câmara de Curitiba de 17 de novembro de 1837, seus membros informavam que embora tivessem sido avisados pela presidência da província da chegada dos caixotes com os utensílios, os mesmos não haviam sido encontrados na alfândega de Paranaguá38. Em outubro do mesmo ano, a Câmara levou ao conhecimento do presidente da província "as contas e documentoz da despeza feita com o arranjo material da Aula de primeiras letras desta Villa pelo methodo Lencasterino" com mesas, bancos e semi-círculos que haviam sido autorizados por portaria de 30 de outubro de $1837^{39}$. Em 1838, "dous caixotes com utensílios para o ensino mutuo das escolas [...] foram entregues ás duas escolas existentes em Curityba" (B. A. M. C., v. 49, 1838, p. 92).

Verificamos que o professor recebeu, ao menos, esta primeira remessa dos materiais solicitados para o ensino pelo método lancasteriano. Em 1841, voltava a enfrentar dificuldades para o recebimento de uma nova remessa de utensis reclamando da demora do correio terrestre em comparação com o correio marítimo ${ }^{40}$. No dia 10 de fevereiro de 1841, o mestre enviava um novo ofício, referente aos utensílios para as suas aulas. Nas instruções minuciosas que ele deu para o encaminhamento dos utensílios, desde o Rio de Janeiro em direção à alfândega de Paranaguá e de lá para a Coletoria da Vila de Curitiba para "satisfazer a despesa da condução", o professor demonstrava possuir saberes que lhe possibilitavam viabilizar materialmente as suas aulas.

${ }^{36}$ Este professor lecionou de junho de 1833 a julho de 1834 (cf KUBO, 1982, anexo 3, s/p).

37 Ofício do professor Firmino Ferreira dos Santos à Câmara Municipal de Curitiba. 26 de outubro de 1833. AESP. CO 1001.

38 Ofício manuscrito pelos membros da Câmara da Vila de Curitiba dirigido ao Exmo presidente da Província de São Paulo em 17 de janeiro de 1838. Lata: "Série Manuscritos. Ofícios diversos de Curitiba 1841-44". Localização: CO 1003. O professor João d'Abreu Sá Sotto-Maior é um dos 7 membros da Câmara que assinam o ofício.

39 Ofício manuscrito pelos membros da Câmara da Vila de Curitiba dirigido ao Exmo presidente da Província de São Paulo em 22 de outubro de 1838. Lata: "Série Manuscritos. Ofícios diversos de Curitiba 1838-40". Localização: CO 1003. AESP.

${ }^{40}$ A substituição do correio marítimo pelo correio terrestre significava um aumento no tempo gasto, de acordo com os membros da Câmara da Vila de Curitiba, retardando a correspondência em até dois ou três meses. 
Elvira Mari Kubo (1982, p. 308), ao tratar dos métodos de ensino existentes na $5^{\text {a }}$ Comarca da Província de São Paulo, informa-nos que, desde 1825, a Câmara da Vila de Paranaguá solicitava uma aula de primeiras letras pelo método Lancaster, mas que foi em Curitiba, em 1838, que a $5^{\text {a }}$ Comarca inaugurou sua aula pelo método lancasteriano. $O$ método lancasteriano teria sido utilizado até o final de 1841 quando um inspetor ${ }^{41}$ declarou à Câmara que o professor não mais o utilizava. O último indício do ensino mútuo na trajetória do professor data de 14 de julho de 1842, cerca de 4 anos após sua abertura (10 de outubro de 1838). O mesmo tenente Lustosa que havia disponibilizado as chaves do consistório da igreja São Francisco considerou que o professor não ensinava "pelo methodo Lancasteriano". A partir de então, o método mútuo e Lancaster não são mais mencionados nas fontes ${ }^{42}$.

Para Kubo (1982, p. 317), a adoção do método Lancaster apresentava a vantagem da "aquisição de utensílios e de um edifício escolar", visto que a legislação de 1827 não previa "o seu fornecimento a professores que aplicassem outros métodos". A interpretação corrobora a análise de que o professor Brandão fazia uso de um amplo repertório de saberes e habilidades para a melhor viabilizar suas aulas, suas condições materiais e lograr outros cargos na vida pública.

Se a lei de 15 de outubro de 1827 foi um eficiente meio de divulgação do método mútuo, os professores se mostraram eficientes na apropriação das possibilidades - não garantias - de melhoria das condições materiais de suas aulas que ela representava (CERTEAU, 1994). A lei trazia para o campo do possível que o professor cobrasse do governo o fornecimento do prédio e materiais para o ensino. Esta brecha, se não assegurava, abria um canal que possibilitava sucessivas investidas e, em alguns casos, a efetivação de condições materiais mais viáveis.

\section{Comentários finais}

Carlo Ginzburg, em reflexão sobre as pesquisas micro-históricas italianas, destacou a recorrência do artifício da comparação por meio da anamolia e não da analogia) na referida historiografia. Ele retoma a expressão "exceção normal" cunhada por Edoardo Grendi (1977) e ressalta a "potencialidade da documentação mais improvável" (GINZBURG, 2007, p. 277). De acordo com Sandra Pesavento, a noção de "excepcional normal" carrega dois sentidos "o do registro só aparentemente excepcional, mas que constitui uma prática vulgar na cotidianidade da vida" ou "de que justamente o excepcional, a transgressão, a marginalidade e o desvio podem dar conta da norma" (PESAVENTO, 2004, p. 180). Assim, registros indiretos e/ou excepcionais possibilitam a compreensão do cotidiano de uma cultura. No prefácio de "O queijo e os vermes", o autor tece algumas considerações sobre o tema, embora ainda não utilize a denominação "excepcional normal". A narrativa sobre Menocchio - um moleiro friulano "queimado por ordem do Santo Ofício, depois de uma vida transcorrida em total anonimato" (GINZBURG, 2006, p. 11) permitiu que uma "investigação que no início girava em torno de um indivíduo aparentemente fora do comum" desembocasse numa "hipótese geral sobre a cultura popular (p. 10)". A singularidade de Menochio, um camponês bastante atípico, é

\footnotetext{
41 Sessões da Câmara Municipal de Curitiba, 13 e 14 de janeiro de 1842. B.A.M.C., v. 53, p. 45-47, 1931.

42 A única referência indireta se dá com a citação que o professor João Baptista Brandão de Proença faz de Degerando no "parecer" de 1854, mas sem fazer nenhuma menção o ensino mútuo.
} 
interpretada nos "limites bem precisos da cultura do próprio tempo e da própria classe" (p. 20).

João Baptista Brandão de Proença não foi tão atípico no grupo de professores oitocentistas quanto Menocchio entre os moleiros italianos do século XVI. Contudo, o repertório acumulado e o trânsito por diversos lugares sociais permitiram que o mestre vivesse uma experiência singular. Ele foi o professor de primeiras letras com maior visibilidade social da geração dos mestres da 5a Comarca. Destacou-se por sua produção escrita, valeu-se das "possibilidades de diálogo com as autoridades administrativas competentes acerca das questões educacionais que circulavam nos Oitocentos" (SCHUELER, 2008, p. 2) que as comunicações oficiais representavam. Elaborou e reivindicou, sucessivas vezes, melhores salários e condições materiais - edifício, "utensis". Outra característica relevante foi o envolvimento e a atuação expressiva desse professor em diversas outras atividades, para além da atuação docente nas escolas públicas primárias. Os indícios da trajetória docente de Brandão de Proença permitem apreender que o professor construiu um repertório de saberes e habilidades que conjugavam diferentes aspectos do ofício e que ele o utilizou de forma tática ou estratégica dependendo do lugar sócio-político que ocupava.

Ingressou no magistério em 1835 e, a partir de 1838, esforçou-se para implementar o método mútuo, apropriando-se da lei como uma forma de melhorar as condições materiais de suas aulas, o que concretamente significou o recebimento de materiais pedagógicos e um edifício com melhores condições. Desde 1845 até a emancipação da 5aㅡ Comarca, em 1853, fez repetidas investidas na busca de melhores ordenados, remetendo ofícios ao governo da Província de São Paulo, tentou se mover em um espaço alheio buscando um momento para dar o golpe colocando em ação diferentes táticas (CERTEAU, 1994). Enquanto professor de uma cidade da $5^{\mathrm{a}}$ Comarca, o professor não logrou êxito.

Quando a localidade em que vivia se tornou a capital de uma nova província do império, seu lugar social se alterou. A mudança política abriu novas possibilidades e o professor capturou a potencialidade do momento. Imediatamente após a instalação da província, conseguiu o aumento de ordenados, que vinha solicitando há mais de 10 anos, por meio de uma representação ao governo da Província do Paraná. Mas foi além, ciente de que uma nova província teria que elaborar sua legislação, valeu-se da escrita - ainda em 1854 com um "parecer" enviado ao primeiro presidente Zacarias Góes e Vasconcellos - para manifestar a necessidade de aumento dos ordenados dos professores de primeiras letras como uma das condições para a melhoria da Instrução Pública. Três anos depois, uma legislação aumentando significativamente os ordenados dos professores foi regulamentada na província. O professor foi conquistando um lugar próprio de ação, que Ihe permitia ações estratégicas, um:

[...] lugar [que] permitia não apenas o acúmulo das conquistas efetuadas, mas o domínio dos espaços pela visão. Oferecia ao sujeito a capacidade de prever e controlar (o presente, o passado e o futuro). Conferia-lhe, por fim, um tipo específico de saber, produzido pelo poder, simultaneamente responsável por sua sustentação. (VIDAL, 2005, p. 276)

Se sua aposentadoria em 1859 o afastou dos bancos escolares, a trajetória e o prestigio angariados como professor permitiram que permanecesse 50 anos na vida pública, no cargo de Juiz de Paz, vindo a falecer em 1891. Personagem "excepcional 
normal”, como consideraria Carlo Ginzburg (2007, p. 277), João Baptista Brandão de Proença indicia os percalços sofridos e as astúcias empregadas pelos primeiros mestres Oitocentistas na produção da profissão docente. Simultaneamente, sua experiência nos espaços públicos porque circulou revela-nos os modos de fazer, viver e sentir a política na primeira metade do século XIX.

\section{Referências}

BAHLS, Aparecida Vaz da Silva. A Busca de Valores Identitários: A Memória Histórica Paranaense. 2007, 207f., Tese (Doutorado em História) - Programa de Pós-Graduação em História, Universidade Federal do Paraná, Curitiba, 2007.

BASTOS, Maria Helena C. A formação de professores para o ensino mútuo no Brasil: O "Curso normal para professores de primeiras letras do Barão de Gérando (1839)". História da Educação. Pelotas: ASPHE/UFPel, n. 3, 1998, p. 958-119.

BOTO, Carlota.O professor primário português como intelectual: Eu ensino, logo existo. Revista da História das Idéias, Coimbra, Faculdade de Letras de Coimbra, v. 24, 2003, p. 85-134.

CÂNDIDO, ANTÔNIO. Um funcionário da Monarquia: ensaio sobre o segundo escalão. Rio de Janeiro: Ouro sobre Azul, 2002.

CERTEAU, Michel de. A Invenção do cotidiano. Artes de fazer. Petrópolis: Vozes, 1994.

FARIA FILHO, L. M. e ROSA, W. M "O ensino mútuo em Minas Gerais (1823-1840)". In: BASTOS, M. H. e FARIA FILHO, L. M. (Orgs.). A Escola elementar no século XIX: o método monitorial/mútuo. Passo Fundo-RS: Ediupf, 1999, p. 177-196.

FLORY, Thomas. El juez de paz e El jurado en El Brasil imperial. México: Fundo de Cultura Econômica, 1986.

GINZBURG, Carlo. O fio e os rastros. São Paulo: Cia das Letras, 2007.

O queijo e os vermes: o cotidiano e as ideias de um moleiro perseguido pela inquisição. São Paulo: Companhia das Letras, 2006.

GOMES, Ângela de Castro. História, historiografia e cultura política no Brasil: algumas reflexões. In SOIHET, Rachel; BICALHO, Maria Fernanda B.; GOUVÊA, Maria de Fátima (orgs). Culturas políticas: ensaios de história cultural, história política e ensino de história. Rio de Janeiro: Mauad, 2005, p. 21-41.

GRENDI, Edoardo. Micro analisi e storia sociale. Quaderni Storici, 1977, p. 506-520.

GRINBERG, Keila. Justiça. In: VAINFAS, R. Dicionário do Brasil Imperial (1822-1889). Rio de Janeiro: Objetiva, 2008, p. 452.

HOLANDA, Sérgio Buarque. História geral da civilização brasileira. São Paulo: Difusão Européia do Livro, 1967.

INÁCIO, Marcilaine Soares. A escola de ensino mútuo de Diamantina: um caso especial. Congresso de Pesquisa e Ensino em História da Educação em Minas Gerais, III, 2005, São João del-Rei. Anais... Universidade Federal de São João del-Rei/MG, 2005, p. 1-15. KUBO, Elvira Mari. A legislação e a instrução pública de Primeiras Letras na 5aㅡ Comarca da Província de São Paulo (Paraná) - 1827-1853. 1982. 375f. Tese (Doutorado em História) - Programa de Pós-Graduação em História da Faculdade de Filosofia Letras e Ciências Humanas, USP, São Paulo, 1982.

LEÃO, Ermelino Agostinho de. Contribuições Historicas e Geographicas para o 
Diccionario do Parana por Ermelino Agostinho de Leão. Impresso nas Officianas da Empresa Graphica Paranaense de Placido e Silva \&cia. LTDA. Rua 15 de novembro, $53-$ Caixa R. Curityba, 1926.

MARTINS, Romário. História do Paraná. São Paulo: Rumo, 1939.

MIGUEL, Maria Elisabeth Blanck (Org.). Coletânea da documentação educacional paranaense no período de 1854 a 1889. Campinas/SP: Autores Associados; SBHE, 2000.

MUNHOZ, Fabiana Garcia. Experiência Docente no Século XIX. Trajetórias de professores de primeiras letras da 5ํㅡㄹ Comarca da Província de São Paulo e da Província do Paraná. 2012. Dissertação (Mestrado em Educação) - Programa de pós-graduação em Educação da Faculdade de Educação da Universidade de São Paulo, São Paulo, 2012.

NEGRÃO, Francisco. Genealogia Paranaense. Curitiba: Impressora Paranaense, 1926.

NICOLAS, Maria. Cem anos de vida parlamentar - Deputados Provinciais e Estaduais do Paraná - Assembleias Legislativas e Constituintes (1854-1954). Curitiba: Paraná, 1954.

NÓVOA, Antônio. O passado e o presente dos professores. In: . Profissão professor. Porto: Porto Editora, 1995. p. 13-34.

OLIVEIRA, Ricardo Costa de. O Silêncio dos Vencedores. Genealogia, Classe Dominante e Estado no Paraná. Curitiba: Moinho do Verbo, 2001.

PESAVENTO, Sandra. O corpo e a alma do mundo. A micro-história e a construção do passado. História Unisinos, v. 8, n. 10, jul./dez. 2004, p. 179-189.

PROENÇA, João Baptista Brandão. "O ensino primário em 1854". Boletim do Arquivo do Paraná. Curitiba, Departamento Estadual de Arquivo e Microfilmagem do Paraná, v. 4, 1979, p. 47-50.

SCHUELER, Alessandra F. M. Professores primários como intelectuais da cidade: um estudo sobre produção escrita e sociabilidade intelectual (corte imperial, 1860-1889). Revista de Educação Pública. Universidade Federal do Mato Grosso, n. 17, 2008, p. 563577.

STRAUBE, Ernani Costa. Símbolos. Brasil, Paraná e Curitiba. Histórico e Legislação. Curitiba, Estante Paranista, 2002. Costumes em comum. Trad. Rosaura Eichemberg. São Paulo: Companhia das Letras, 1998.

THOMPSON, Edward Palmer. Senhores e Caçadores. Rio de Janeiro: Paz e Terra, 1987. VIDAL, Diana Gonçalves. Michel de Certeau e a difícil arte de fazer história das práticas. In. FARIA FILHO, Luciano Mendes de (Org.). Pensadores sociais e história da educação. Belo Horizonte: Autêntica, 2005, p. 257-284.

FABIANA GARCIA MUNHOZ é professora da Educação Básica da Prefeitura de Rio Claro-SP. Mestra e doutoranda em Educação pela Universidade de São Paulo e bolsista CAPES. Integrante do Núcleo Interdisciplinar de Estudos e Pesquisa em História da Educação (Niephe-USP). Endereço: Estrada Velha de São Carlos, 301, casa 9A - Bairro Granja Regina - 13503-069 Rio Claro/SP - Brasil

E-mail: fgmunhoz@gmail.com 
DIANA GONÇALVES VIDAL é professora Titular da Faculdade de Educação da Universidade de São Paulo, onde atualmente exerce a vice-direção e coordena o Núcleo Interdisciplinar de Estudos e Pesquisa em História da Educação (Niephe-USP). É pesquisadora CNPq e membro do Comitê Executivo da International Standing Conference for the History of Education (Ische).

Endereço: Av. da Universidade, 308 - Cidade Universitária - 05508-040 - São Paulo/SP - Brasil E-mail: dvidal@usp.br

Recebido em 08 de novembro de 2016.

Aceito em 11 de janeiro de 2017. 